\title{
Erzurum yöresi 2002-2004 ve 2010-2012 yıllarında saptanan özofagus kanserlerinin karşılaştırılması
}

\section{Comparison of esophageal cancer patients in the Erzurum region in two periods (2002-2004 and 2010-2012)}

\author{
Ahmet UYANIKOĞLU${ }^{1}$, Doğan Nasır BINICI ${ }^{2}$, Muharrem COŞKUN ${ }^{3}$ \\ Harran Universitesi, Tip Fakültesi, ${ }^{1}$ Gastroenteroloji Bilim Dal, Sanlıurfa \\ Erzurum Bölge Eğitim Hastanesi, ${ }^{2}{ }^{1 c ̧ ~ H a s t a l k k l a n ~ K l i n i g ̆ i, ~ E r z u r u m ~}$ \\ Istanbul Eğitim ve Araştırma Hastanesi, ${ }^{3}$ Gastroenteroloji Kliniği, Istanbul
}

\begin{abstract}
Giriş ve Amaç: Doğu Anadolu Bölgesinde özofagus kanseri diğer bölgelere göre daha sıktır. Erzurum Bölge Eğitim ve Araştırma Hastanesi Endoskopi Ünitesinde 2 farklı dönemde özofagus kanseri saptanan hastaların karşılaştırılması amaçlanmıştır. Materyal ve Metod: 2002-2004 (1. Dönem) ve 2010-2012 (2. Dönem) yıllarında retrospektif olarak, ünitemizde özofagus kanseri saptanan hastaların yaş, cinsiyet, tümör lokalizasyonu ve patolojik tanılarının karşılaștırılması amaçlanmıștır. Özofagusta saptanan lezyonların yerleşim yerleri ve histopatolojik özellikleri Dünya Sağlık Örgütü sinıflaması dikkate alınarak değerlendirilmiştir. Bulgular: 1. Dönem özofagus kanserli 79 hastanın 41 'i erkek (\%52), yaş aralığı 21-92, ortalama tanı konma yaşı 60 idi. 2. Dönemde 9'u özofajektomi-özofagogastrostomili toplam 71 hastanın 34'ü (\%48) erkek, yaş aralı̆̆ 38-87, ortalama tanı konma yaşı 64 yaş idi. Iki dönem arasında yaş ve cinsiyet dağılımı açısından anlamlı fark yoktu $(p>0,5)$. 1. Dönem hastalarnn tümörün orta özofagusta yerleşme oranı fazla idi ( $p<0,05)$. 1. Dönem hastaların 57'si (\%72) yassı epitel hüceli tümör, 19 'u (\%24) adenokanser, 3'ü (\%6) indiferansiye kanser, 2. Dönem biyopsi sonucuna ulaşılabilen 49 hastanın 37'si (\%75) yassı epitel hücreli kanser, 6'sı (\%12) adenokanser, 4'ü (\%8) indiferansiye kanser, birer hasta papiller adenokanser ve küçük hücreli kanser idi. Her iki dönemde en sık görülen kanser yassı epitel hücreli kanser olup, ilk dönemde adenokanser iki kat fazla saptanmıştır $(p<0,05)$. Sonuç: Bir dekat arayla özofagus kanseri saptanan hastalar karşılaştırıldığında iki dönem arasında yaş, cinsiyet dağılımı benzer olup her iki dönemde en sık yerleşim yeri distal, en sik görülen histopatolojik tip yassı epitel hücreli kanser idi. Bir dekat öncesine göre özofagus kanserinde distal yerleşim sıklığının arttığı, histopatolojik tip olarak adenokanserin azaldığı saptanmıştır.
\end{abstract}

Anahtar kelimeler: Özofagus kanseri, yassı epitel hücreli kanser, adenokanser

\section{GİRIŞ}

Özofagus kanseri ileri derecede agresif seyretmesi ve kötü prognozu nedeniyle dünya çapında kanserden ölümlerin en önemli nedenlerinden biridir. Tüm kanser ölümlerinin en sık 6. nedenidir. Retrospektif çalışmalar sigara, sıcak içecekler, kırmızı et tüketimi, kötü ağı hijyeni, az sebze ve meyve tüketimi ve düşük sosyoekonomik nedenler ve genetik nedenlerin özofagusun yassı epitel hücreli kanseri ile ilişkili olduğunu göstermiştir. Barrett özofagus (BÖ) risk faktörü olarak tanımlanmış olup, klinik pratikte displazi, adenokanser gelişimi için artmış riski gösteren en kullanışlı bulgudur. Gastroözofageal reflü hastalığı (GÖRH) semptomları, diyet faktörleri ve
Background and Aims: Esophageal cancer is more common in the Eastern Anatolian region than in other regions. We aimed to compare patients detected to have esophageal cancer in the Erzurum Regional Training and Research Hospital, Endoscopy Unit, in two time periods. Materials and Methods: Age, gender, tumor localization, and pathological diagnosis of patients with esophageal cancer seen in our unit from 2002-2004 ( $1^{\text {st }}$ period) and from 2010- 2012 ( $2^{\text {nd }}$ period) were compared retrospectively. Localizations and histopathological features of esophageal lesions were evaluated according to the World Health Organization classification. Results: Among 79 patients with esophageal cancer seen in the $1^{\text {st }}$ period, 41 were male (52\%), the age range was 21-92 years, and the mean age at diagnosis was 60 years. In the $2^{\text {nd }}$ period, 34 of 71 patients were male (48\%), the age range was 38-87 years, and the mean age at diagnosis was 64 years. There were no significant differences in terms of age and gender distribution between the two periods $(p>0,5)$. Mid-esophageal localization of tumors was higher in the $1^{\text {st }}$ period ( $p<0,05)$. Among patients seen in the $1^{\text {st }}$ period, $57(72 \%)$ had squamous cell cancer, 19 (24\%) adenocarcinoma, and 3 (4\%) undifferentiated cancer, while in the $2^{\text {nd }}$ period, 53 (75\%) had squamous cell cancer, 9 (12\%) adenocarcinoma, $6(8 \%)$ undifferentiated carcinoma, 1 (1,5\%) papillary adenocarcinoma, and 2 (3\%) small cell lung cancer. In both time periods, the most common cancer was squamous cell cancer, while adenocarcinoma was seen at a two-fold higher rate in the first period $(p<0,05)$. Conclusions: $A$ comparison of patients with esophageal cancer seen 10 years apart revealed that age and sex distribution were similar; the most common localization was distal; and the most common histological type was squamous cell cancer. In the $2^{\text {nd }}$ period, the localization was higher distal esophageal cancer and adenocarcinoma among the histopathologic types had decreased when compared to the $1^{\text {st }}$ period.

Key words: Esophageal cancer, squamous cell cancer, adenocarcinoma

sigara özofagus kanseri için en önemli risk belirleme faktörleridir (1-4).

Amerika Birleşik Devletlerinde özofagus adenokanser ve gastrik kardiya kanser insidansı 1973'ten 2009'a yaklaşık \%400 artmıştır. İn situ kanser tanısı 2000 yllından itibaren artmaya başlamasına rağmen halen in situ kanser tanı koyma sıklı̆̆ $\% 2,5$ 'un altindadir (5).

Uzakdoğuda yapılan bir çalışma sonuçlarına göre özofageal kanserlerin büyük kısmı yassı epitel hücreli kanserlerdir (\%82). Kardiya kanserleri ise majör gastrik kanser grubudur
Bu çalışma 20-25 Kasım 2012, 29. Ulusal Gastroenteroloji Kongresinde sözlü bildiri olarak sunulmustur.

Uyanıkoğlu A, Binici ND, Coşkun M. Comparison of esophageal cancer patients in the Erzurum region in two periods (2002-2004 and 2010-2012). Endoscopy Gastrointestinal 2014; 22: 4-7.
İletişim: Ahmet UYANIKOĞLU Harran Üniversitesi, Tıp Fakültesi, Gastroenteroloji Bilim Dalı, Şanlıurfa E-posta: auyanikoglu@hotmail.com•Web: ahmetuyanikoglu.com Geliș Tarihi: 02.03.2014 Kabul Tarihi: 31.03.2014 
(\%64). 2003-2009 arasındaki dönemde özofagus yassı epitel hücreli kanser ve gastrik kardiyak kanser insidansı artmıştır. Her iki kanser insidansı erkeklerde kadınlara göre daha yüksek bulunmuştur. Tüm subgruplarda sürvi kötü olup, 1 ylllık $\% 45,9-\% 65,6,5$ ylllı \%14,7-\%30,5 arasindadır (6). 19982008 ylları arasında radyoterapinin tedavide kullanımı özellikle ilerlemiş orta ve distal özofagus kanserinde artmıştır. En iyi sağkalım cerrahi ve radyoterapinin birlikte kullanılması ile sağlanmaktadır (7).

Özofagus adenokanser insidansı batı dünyasında hızlı bir şekilde artmaktadır. Obezite ve diğer hayat sitili ile ilgili faktörlerin bu artıştan sorumlu olduğu düşünülmektedir (8).

Ülkemizde özofagus kanseri en sık Doğu Anadolu Bölgesinde görülmekte olup, bu bölgede endemiktir $(9,10)$.

Bu çalışmada Erzurum Bölge Eğitim ve Araştırma Hastanesi Endoskopi Ünitesinde bir dekat arayla iki farklı dönemde özofagus kanseri saptanan hastaların karşılaştırılması amaçlanmıştır.

\section{MATERYAL ve METOD}

2002-2004 (1. Dönem) ve 2010-2012 (2. Dönem) yllarında retrospektif olarak, ünitemizde özofagus kanseri saptanan hastaların yaş, cinsiyet, tümör lokalizasyonu ve patolojik tanıları karşılaştırılmıştır. Özofagusta saptanan lezyonların yerleşim yerleri ve histopatolojik özellikleri Dünya Sağllk Örgütü (WHO) sınıflaması dikkate alınarak değerlendirilmiştir. Istatistiki değerlendirmeler SPSS programı kullanılarak yapılmıştır.

\section{BULGULAR}

1. Dönem özofagus kanserli 79 hastanın 41 'i erkek (\%52), yaş aralığı 21-92, ortalama tanı konma yaşı 60 idi. 2. Dönemde 9'u özofajektomi-özofagogastrostomili toplam 71 hastanın 34 'ü (\%48) erkek, yaş aralığı 38-87, ortalama tanı konma yaşı 64 yaş idi. İki dönem arasında yaş ve cinsiyet dağılımı açısından anlamlı fark yoktu ( $>0,5)$ (Tablo 1).

1. Dönem hastaların tümör lokalizasyonu değerlendirildiğinde 2'si (\%3) proksimal, 34'ü (\%43) orta, 43 (\%54)'ü distal yerleşimli iken, 2. Dönemde yerleşim değerlendirmesi yapılan 62 vakanın 18'i (\%30) orta, 44’ü (\%70) distal yerleşimli idi. Ilk dönemde saptanan kanserlerin orta özofagusta yerleşme oranı fazla idi $(\mathrm{p}<0,05)$ (Tablo 2).

1. Dönem hastaların 57'si (\%72) yassı epitel hüceli kanser, 19 'u (\%24) adenokanser, 3'ü (\%6) indiferansiye kanser tanısı almıştır. 2. Dönem biyopsi sonucuna ulaşılabilen 49 hastanın 37'si (\%75) yassı epitel hücreli kanser, 6'sı (\%12) adenokanser, 4’ü (\%8) indiferansiye kanser, birer hasta papiller adenokanser ve küçük hücreli kanser olarak rapor edilmiştir. Her iki dönemde en sık görülen kanser yassı epitel hücreli kanser olup, ilk dönemde adenokanser ikinci döneme göre iki kat fazla saptanmıştır $(\mathrm{p}<0,05)$ (Tablo 3).

Tablo 1. Özofagus kanserli hastaların demografik özellikleri

İncelenen dönemler

1. Dönem (2002-2004)

2. Dönem (2010-2012)

Sayı (n)

79 hasta

71 hasta

Cinsiyet*

41'i (\%52) erkek

34'ü (\%48) erkek

Yaş aralığ ${ }^{*}$

21-92 yaş

38-87 yaş

Ortalama tanı konma yaşı

60 yaş

64 yaş

* Iki dönem arasında yaş ve cinsiyet dağılımı açısından anlamlı fark yoktu $(\mathrm{p}>0.5)$.

Tablo 2. Özofagus kanserlerinin yerleşim yeri

\begin{tabular}{lcc} 
İncelenen dönemler & 1. Dönem (2002-2004) & 2. Dönem (2010-2012) \\
\hline Proksimal & $2(\% 3)$ & \\
\hline Orta* & $34(\% 43)$ & $18(\% 30)$ \\
Distal & $43(\% 54)$ & $44(\% 70)$
\end{tabular}

*Ilk dönemde orta özofagusta yerleşme oranı fazla idi $(\mathrm{p}<0.05)$.

Tablo 3. Özofagus kanserlerinin histopatolojik özellikleri

İncelenen dönemler

Yassı epitel hücreli tümör

Adenokanser*

İndiferansiye karsinom

Diğer

*11k dönemde adenokanser iki kat fazla idi $(\mathrm{p}<0.05)$

\section{TARTIŞMA}

Özofagus kanserinde risk faktörü olarak cinsiyet faktörünün önemi net değildir. Son çalışmalar hormonal faktörlerin önemli olabileceğini göstermiştir (11). Bizim çalışmamızda bir dekat arayla saptanan özofagus kanserlerinde her iki dönemde, erkek kadın oranlarının birbirine yakın olduğu ve dönemsel olarak oranların değişmediği saptanmıştır.

Her gün kırmızı et yenilmesi, oral kavite, farenks, nazofarenks, özofagus, kolon, rektum, pankreas, göğüs, endometrium ve over kanser ile ilişkili bulunmuştur, pişirme şeklinin de kanser gelişiminde etkisi olduğu saptanmıştır (12). Kahve alışkanlığı özofagus kanser riskini azaltırken, yeşil çayın arttırabileceği bildirilmiştir. Alkol de riski arttırmaktadır (13, 14). Doğu Anadolu Bölgesi ve Erzurum yöresinde özofagus kanseri endemiktir $(9,10)$. Her ne kadar bu araştırmada beslenme alışkanlıkları sorgulanmamış olsa da gözlemsel olarak bölgede fazla miktarda kırmızı et tüketimi, çay tüketiminin fazla olması özofagus kanserinin bölgesel nedenlerinin ikisi olabileceği speküle edilebilir. 
Özofagus adenokanser insidansı batı dünyasında hılı bir şekilde artmaktadır. Obezite ve diğer hayat sitili ile ilgili faktörlerin bu artıştan sorumlu olduğu düşünülmektedir. Ancak obeziteyi içeren hayat tarzı alışkanlıkları özofagus adenokanserin internasyonal seyrini izah etmemektedir (8). Bizim ülkemiz ve bölgemiz için ise yassı epitel hücreli kanser daha ciddi ve yaygın bir problemdir. Adenokanser için BÖ gibi iyi tanımlanmış risk faktörleri, yassı epitel hücreli kanser için geçerli değildir. Bu nedenle erken tanı ve tedavi ihtimali daha düşüktür. Ülkemiz ve özellikle bölgemiz için yassı epitel hücreli kanser açısından erken tanı için tarama programları geliştirilmelidir. Bir dekat arayla her iki seride ortalama tanı konma yaşı 60 civarında olduğu düşünülürse 50 yaş sonrası tarama programları geliştirilebilir. Bölgede erken endoskopik tedavi modalitelerinin uygulanabilir olması, cerrahi tedavi ve radyoterapi imkanların geliştirilmesi düşünülmelidir.

Obezite ile endometrial, özofagus adenokanser, kolorektal, postmenapozal gögüs, prostat ve renal kanser arasında güçlü ilişki gösterilmiştir. Dört temel sistem; insülin, insülin benzeri büyüme faktör inhibitörü, seks steroidleri ve adipokinler obezitede potansiyal kanser yolakları olarak tanımlanmıştır (15). Fiber diyetinin antikanserojenik pek çok özelliği olup özofagus kanserinde özellikle adenokanserde koruyucu olduğu düşünülmektedir. GÖRH ve/veya kilo kontrolünün koruyucu olabileceği bildirilmiştir (16). Batıda her ne kadar obezite, reflü artışı dolaysıyla da adenokanser artışı bildirilirse de bizim çalışmamızda bir önceki dekatta adenokanserin iki kat daha sık saptanması bu trendin bölge için geçerli olmadığını düşündürmüştür.

Özofagus adenokanserinin insidansı artmaktadır, erkeklerde fazladır, önleme ve erken saptama ihtimali vardır, cerrahi tedavi mümkündür ve kötü prognozludur. İnsidansındaki hızlı artış GÖRH ve obezitenin artması, Helicobacter pylori prevalansının azalmasına bağlanmaktadır. Erkek dominansı açıklanamamakta ancak hormonal faktörlerin etkili olduğu düşünülmektedir. GÖRH ve obezitenin tedavisi ve nonstero-

\section{KAYNAKLAR}

1. Zhang Y. Epidemiology of esophageal cancer. World J Gastroenterol. 2013; 19:5598-606.

2. Li WQ, Hu N, Wang Z, et al. Genetic variants in epidermal growth factor receptor pathway genes and risk of esophageal squamous cell carcinoma and gastric cancer in a Chinese population. PLoS One 2013; 8:e68999.

3. Navarro Silvera SA, Mayne ST, Gammon MD, et al. Diet and lifestyle factors and risk of subtypes of esophageal and gastric cancers: classification tree analysis. Ann Epidemiol 2014; 24:50-7.

4. Akbas H, Uyanikoglu A, Aydogan T, et al. E-Cadherin (CDH1) Gene160C >A promotor polymorphism and risk factor of gastric and esophageal cancers. Acta Medica Mediterranea 2013; 29:671.

5. Dubecz A, Solymosi N, Stadlhuber RJ, et al. Does the incidence of adenocarcinoma of the esophagus and gastric cardia continue to rise in the twenty-first century?-a SEER database analysis. J Gastrointest Surg 2013 Nov 15. [Epub ahead of print]. id antiinflamatuvar ve statinlerle kemoprevansiyon özofagus adenokanseri gelişimini önleyebilir, ancak henüz yeterli kanıt mevcut değildir. Endoskopik taramalar dahil gelişmeler yüksek riskli grupların daha iyi tanımlanmasını sağlayacaktır. BÖ'lü hastaların özellikle displazili hastaların kişiselleştirilmiş takipleri faydalı olabilir, ancak takip ve tarama için strateji ve fayda-maliyet oranının iyi belirlenmesi gerekir. Cerrahi tedavi diğer yöntemlere göre daha fazla yer almaktadır, ancak post-operatif sağkalım, yaşam kalitesi ve beslenme iyileştirilmelidir. Displastik BÖ veya erken adenokanserde preoperatif kemoradyoterapi, minimal cerrahi ve yeni endoskopik teknikler gibi klinik gelişmeler umut vermektedir. Sağkalım oranları hafifçe iyileşmesine rağmen halen kötü prognozludur (17). Bizim hasta gruplarımızda erkek dominansı saptanmamıştır. Bölgede risk faktörlerinin iyi belirlenerek önlem alınması, riskli hastaların takibi faydalı olacaktır.

GÖRH'nın komplikasyonlarından BÖ, özofageal adenokanser için risk faktörüdür. Özofageal adenokanser insidansı geçmiş dekatlara göre 7 kattan fazla artmıştır. Displazi olmadan BÖ saptandığında endoskopik takibin 3-5 yılda bir yapılması önerilmektedir. Endoskopik eradikasyon tedavisi opsiyonel olarak düşük dereceli displazide ve yüksek dereceli displazi saptandığında seçilecek yöntemdir. Nondisplastik BÖ'da endoskopik eradikasyon tedavisi önerilmez (18). Araştırmamızda BÖ değerlendirilmemiş olmakla birlikte, adenokanser insidansında artış değil tam tersi düşüş saptanmıştır.

Sonuç olarak bir dekat arayla özofagus kanseri saptanan hastalar karşılaştırıldığında iki dönem arasında yaş ve cinsiyet dağılımı benzer olup her iki dönemde en sık yerleşim yeri distal, en sık görülen histopatolojik tip yassı epitel hücreli kanser idi. Yassı epitel hücreli özofagus kanseri ülkemiz ve bölgemiz için önemli bir sağlık sorunudur. 50 yaş sonrası tarama programları geliştirilmeli, erken endoskopik tedavi, cerrahi tedavi ve radyoterapi imkanları geliştirilmelidir. Bir dekat önce orta özofagusta daha fazla oranda yerleşim ve yaklaşık iki kat daha sık adenokanser saptanmıştır.

6. Liu SZ, Wang B, Zhang F, et al. Incidence, survival and prevalence of esophageal and gastric cancer in linzhou city from 2003 to 2009. Asian Pac J Cancer Prev 2013; 14:6031-4.

7. Worni M, Castleberry AW, Gloor B, et al. Trends and outcomes in the use of surgery and radiation for the treatment of locally advanced esophageal cancer: a propensity score adjusted analysis of the surveillance, epidemiology, and end results registry from 1998 to 2008. Dis Esophagus 2013 Aug 13. [Epub ahead of print]

8. Kroep S, Lansdorp-Vogelaar I, Rubenstein JH, et al. Comparing trends in esophageal adenocarcinoma incidence and lifestyle factors between the United States, Spain, and The Netherlands. Am J Gastroenterol 2014; 109:336-43; quiz 335, 344. Epub 2013 Dec 17. 
9. Uyanıkoğlu A, Coşkun M, Binici DN, et al. Doğu Anadolu Bölgesinde Üst GIS Kanseri Saptanan Hastaların Gastroskopi ve Biyopsi Sonuçları [Eastern Anatolia Region Gastroscopy and Biopsy of Patients with Gastrointestinal Cancer]. Dünya Gastroenteroloji Derneği Bölgesel Toplantısı ve 28. Ulusal Gastroenteroloji Haftası [WGO Regional Meeting With The 28th Turkish Gastroenterology Week]. 16-20 Kasim 2011 Antalya. Turk J Gastroenterol 2011; 22(Supp1): P-24, 129.

10. Uyanıkoğlu A, Coşkun M, Binici DN, et al. Erzurum yöresi gastroskopi ve patoloji sonuçlarının değerlendirilmesi [Evaluation of gastroscopic and pathologic results Erzurum Region]. Türkiye Klinikleri J Gastroenterohepatol 2011; 18:70-4.

11. Mathieu LN, Kanarek NF, Tsai HL, et al. Age and sex differences in the incidence of esophageal adenocarcinoma: results from the surveillance, epidemiology, and end results (SEER) Registry (1973-2008). Dis Esophagus. 2013 Oct 7. [Epub ahead of print]

12. Di Maso M, Talamini R, Bosetti C, et al. Red meat and cancer risk in a network of case-control studies focusing on cooking practices. Ann Oncol 2013; 24:3107-12.
13. Oze I, Matsuo K, Kawakita D, et al. Coffee and green tea consumption is associated with upper aerodigestive tract cancer in Japan. Int J Cancer 2014; 135:391-400. Epub 2013 Dec 17.

14. Tanaka H. Advances in cancer epidemiology in Japan. Int J Cancer 2014; 134:747-54. Epub 2013 Oct 22.

15. De Pergola G, Silvestris F. Obesity as a major risk factor for cancer. J Obes 2013; 2013:291546.

16. Coleman HG, Murray LJ, Hicks B, et al. Dietary fiber and the risk of precancerous lesions and cancer of the esophagus: a systematic review and meta-analysis. Nutr Rev 2013; 71:474-82.

17. Lagergren J, Lagergren P. Recent developments in esophageal adenocarcinoma. CA Cancer J Clin 2013; 63:232-48.

18. Spechler SJ. Barrett esophagus and risk of esophageal cancer: a clinical review. JAMA 2013; 310:627-36. 